\title{
Aplikasi Campus Learning System iOU (integrated Online Ujian) Dalam Mendukung Kegiatan iLearning Education (iDu) Pada Perguruan Tinggi
}

\author{
Untung Rahardja ${ }^{1}$ \\ Muhamad Yusup ${ }^{2}$ \\ Qurotul Aini ${ }^{3}$ \\ e-mail: untung@raharja.info,yusup@raharja.info,aini@raharja.info
}

Diterima : 23 Januari 2014 / Disetujui : 03 Februari 2014

\begin{abstract}
To determine the quality of a student after going through the learnig process is to test the application on an ongoing basis in order to fix the quality of education. In the world of education universities that have implemented such Raharja learning methods iLearning. But the concept of exams are generally still using paper based which is not in accordanca with the current technological advances. Altenative handling this problem is to implement a campus based learning system of cumputer based iOU. With iOU based computer based students can work on the problems on a computer random exam questions, which also makes the students can work on the problems at the same time but each working on different. In this work there is also a matter of iOU starting adn ending time limit such questions. In the paper, identified al least 5 problems faced regarding the concept paper based exam, the definition of iOU based computer based., and the benefit of this concept iOU exam. The final result of this study can be used to provide improved quality of examinations in universities Raharja to always provide convenience in doing the exam students and faculty in the terms og giving value to students.
\end{abstract}

Keyword : exam, paper based, iOU, computer based

1. Dosen Jurusan Sistem Informasi, STMIK Raharja

Jl. Jend Sudirman No. 40 Modern Cikokol-Tangerang Telp. 5529692

2. Dosen Jurusan Sistem Informasi, STMIK Raharja

Jl. Jend Sudirman No. 40 Modern Cikokol-Tangerang Telp. 5529692

3. Mahasiswa Jurusan Sistem Informasi, STMIK Raharja

Jl. Jend Sudirman No. 40 Modern Cikokol-Tangerang Telp. 5529692 


\section{ABSTRAKSI}

Untuk mengetahui mutu seorang pelajar setelah melewati proses pembelajaran adalah dengan diterapkannya ujian secara berkesinambungan agar dapat membenahi mutu pendidikan. Di dalam dunia pendidikan Perguruan Tinggi Raharja misalnya yang telah menerapkan metode pembelajaran iLearning. Namun konsep ujian dalam metode iLearning tersebut pada umumnya masih menggunakan paper based yang tidak sesuai dengan kemajuan teknologi saat ini. Alternatif penanganan masalah ini adalah dengan menerapkan campus learning system iOU (integrated Online Ujian) berbasis computer based. Dengan iOU yang berbasis computer based mahasiswa dapat mengerjakan soalsoal ujian pada komputer yang merandom soal-soal tersebut, yang juga menjadikan mahasiswa dapat mengerjakan soal dalam waktu yang bersamaan tetapi masing-masing mengerjakan soal berbeda. Dalam pengerjaan soal iOU juga terdapat batas waktu memulai dan mengakhiri soal-soal tersebut. Dan mahasiswa beserta dosen dapat langsung mengetahui nilai akhir dari pengerjaan soal-soal ujian tersebut. Dalam jurnal ini, diidentifikasikan setidaknya 5 masalah yang dihadapi perihal konsep ujian paper based, definisi dari iOU computer based, serta manfaat dari konsep ujian iOU ini. Hasil akhir penelitian ini dapat digunakan untuk memberikan peningkatan mutu ujian pada Perguruan Tinggi Raharja agar senantiasa memberikan kemudahan mahasiswa dalam mengerjakan ujian dan dosen dalam hal memberi nilai kepada mahasiswa.

Kata kunci: ujian, paper based, iOU, computer based

\section{PENDAHULUAN}

Ujian adalah sistem evaluasi standar pendidikan tinggi dan persamaan mutu antar kelas yang dilakukan oleh kampus. Berdasarkan Undang-undang Republik Indonesia nomor 20 tahun 2003 menyatakan bahwa dalam rangka pengendalian mutu pendidikan secara nasional dilakukan evaluasi sebagai bentuk akuntabilitas penyelenggara pendidikan kepada pihak-pihak yang berkepentingan. Lebih lanjut dinyatakan bahwa evaluasi dilakukan oleh kampus secara berkala, menyeluruh, transparan, dan sistematik untuk menilai pencapaian standar pendidikan yang ditentukan oleh kampus dan proses pemantauan evaluasi tersebut harus dilakukan secara berkesinambungan. Proses pemantauan evaluasi tersebut dilakukan secara terus menerus dan berkesinambungan pada akhirnya akan dapat membenahi mutu pendidikan. Pembenahan mutu pendidikan dimulai dengan penentuan standar yang dibuat oleh kampus.

Penentuan standar yang terus meningkat diharapkan akan mendorong peningkatan mutu pendidikan, yang dimaksud dengan penentuan standar pendidikan adalah penentuan nilai batas (cut off score). Seseorang dikatakan sudah lulus permatakuliah bila telah melewati nilai batas tersebut berupa nilai batas antara mahasiswa 
yang sudah menguasai kompetensi tertentu dengan mahasiswa yang belum menguasai kompetensi tertentu. Bila itu terjadi pada Ujian Tengah Semester (UTS) dan atau Ujian Akhir Semester (UAS) maka nilai batas tersebut berfungsi untuk memisahkan antara mahasiswa yang lulus dan mahasiswa yang tidak lulus disebut batas kelulusan per-matakuliah, kegiatan penentuan batas kelulusan tersebut disebut standar setting.

Manfaat pengaturan standar UTS dan atau UAS adalah adanya batas kelulusan setiap matakuliah sesuai dengan tuntutan nilai batas minimum dan juga sebagai standar minimum pencapaian kompetensi.

Dengan di latar belakangi hal tersebut membuat penulis ingin meningkatkan kualitas dari pelaksanaan ujian yang ada. Ujian mengandung satu set soal-soal yang didalamnya berisi materi yang pernah dipelajari sebelumnya di dalam kelas. Sebuah metode pembelajaran juga sangat menentukan hasil atau output yang tercipta dari metode pembelajaran tersebut. Tentu saja semua dibutuhkan fasilitas yang memadai, oleh karena itu terciptalah sebuah metode pembelajaran iLearning. Menurut Untung Rahardja [2011] iLearning adalah mengintegrasikan sumber daya dalam menjalankan dalam menjalankan Tri Dharma Perguruan Tinggi dengan menggunakan iPad, dimana iPad memiliki aplikasi pendukung pembelajaran dan masih banyak lainnya. Sistem iLearning yang ada sudah cukup baik, namun belum efektif dan beragam karena pelaksanaan ujiannya masih terpaku pada konsep paper based. Dengan menggunakan konsep computer based saat pelaksanaan ujian akan menentukan mutu kualitas dalam proses pembelajaran iLearning.

\section{PERMASALAHAN}

Pada dasarnya penelitian itu dilakukan dengan tujuan untuk mendapatkan data yang antara lain dapat digunakan untuk memecahkan masalah. Untuk itu setiap penelitian yang akan dilakukan harus selalu berangkat dari masalah. Masalah adalah kesenjangan (discrepancy) antara apa yang seharusnya (expextation) dengan apa yang ada dalam kenyataan sekarang. Rumusan masalah berbeda dengan masalah. Kalau masalah merupakan kesenjangan antara yang di harapkan dengan yang terjadi, maka rumusan masalah itu merupakan suatu pertanyaan yang akan dicarikan jawabannya melalui pengumpulan data. Namun demikian terdapat kaitan erat antara masalah dengan rumusan masalah, karena setiap rumusan masalah penelitian harus didasarkan pada masalah.

Proses pelaksanaan UTS/UAS menjadi bagian dari proses pembelajaran karena pada bagian ini adalah waktu dimana kualitas mahasiswa diuji. Kualitas yang baik adalah ditentukan dari proses yang sistematis dan memiliki pengalaman yang 
ISSN: 1978 - 8282

luar biasa. Namun pada Perguruan Tinggi Raharja hal tersebut belum tercapai dengan sempurna, dimana masih terdapat banyak proses manual dan melibatkan banyak orang sehingga proses yang berjalan sangat panjang dan sulit. Jika ada satu orang yang menghambat maka seluruh proses menjadi terhambat sampai pada waktu pelaksanaan. Dosen yang masih meluangkan waktu banyak untuk membuat soal, menemui Kajur (Kepala Jurusan) untuk menyerahkan soal tidak mencerminkan hal tersebut adalah proses yang mudah. Bagian terkait RPU juga harus teliti menyiapkan soal yang diserahkan oleh Kajur. banyak dosen yang kurang disiplin dengan menyerahkan soal tidak sesuai dengan format yang menyebabkan RPU harus meluangkan waktu melakukan edit soal. Pada proses ini RPU harus dipastikan bekerja dengan teliti dan cepat. Sehingga bagian RCC (Raharja Copy Centre) bisa langsung melakukan penggandaan soal. Proses penggandaan soal ini harus mengorbankan pemasukkan Perguruan Tinggi Raharja yang berkurang karena RCC akan tutup dalam waktu yang tidak dapat ditentukan untuk menyiapkan soal sehingga mahasiswa tidak dapat memanfaatkan fasilitas yang ada. Dan penggandaan soal membutuhkan kertas yang sangat banyak, tidak jarang terjadi kesalahan fotocopy. Bahkan tinta dan mesin fotocopy harus dipastikan dalam kondisi baik, jika kehabisan tinta atau mesin tersebut sedang mengalami kerusakan maka proses persiapan soal akan terhambat. Kendala tidak berhenti pada bagian ini, selesai proses penggandaan soal kesiapan dan tanggung jawab panitia packing soal diuji karena sering terjadi rasa malas untuk mengerjakan hal ini. Panitia yang mengerjakan 'packing soal harus sejenak meninggalkan rutinitas harian mereka, sehingga pekerjaan rutin menjadi terhambat. Dalam proses ini panitia harus sangat teliti agar tidak terjadi kesalahan dalam packing. Panitia juga harus menyiapkan 1 (satu) ruang untuk meletakkan soal yang telah selesai dipacking. Dan kemudian soal tersebut akan didistribusikan ke bagian Resepsionis. Ruang Resepsionis akan menjadi sempit karena soal yang ada, dan akan ada proses pengambilan soal dari Pengawas yang telah ditentukan oleh bagian RPU dengan menyertakan tanda tangan di tanda terima. Pengawas akan membagikan soal-soal kepada mahasiswa dengan cara berkeliling sesuai dengan kode kelas, pada hal ini terkadang terjadi soal yang tidak sesuai yang menyebabkan kerugian pada pihak mahasiswa. Soal beserta lembar jawaban akan mahasiswa berikan kepada Pengawas dan akan di rapikan kembali untuk diserahkan kepada bagian Resepsionis. Namun Pengawas terkadang kurang disiplin karena tidak langsung menyerahkannya sehingga lupa beberapa waktu. Dan menyebabkan Resepsionis harus call Pengawas tersebut berkali-kali. Soal yang telah dipisahkan dengan lembar jawaban akan diserahkan secara langsung oleh Pengawas kepada dosen yang bersangkutan atau jika dosen tidak berada di tempat akan dititipkan pada bagian Sekretaris Jurusan (Sekjur). Dosen akan menemui Sekjur untuk mengambilnya dan setelah itu akan diberi waktu selama 7 (tujuh) hari setelah 
pelaksanaan ujian untuk mengoreksi lembar jawaban dengan jumlah yang sangat banyak. Namun dosen sering kali tidak tepat waktu dalam pengumpulan nilai sehingga proses pada bagian RPU terhambat. RPU akan menjadikan nilai-nilai yang diterima berdasarkan standar deviasi,nilai tersebut akan dimasukkan ke database. Dan terkadang komputer yang digunakan oleh RPU mengalami kerusakan sehingga proses menjadi banyak hambatan. RPU akan mengirim database pada bagian terkait REC (Raharja Enrichment Centre) untuk kemudian diinput ke dalam SIS (Stundet Information Services). Dengan proses yang begitu panjang beberapa waktu kemudian mahasiswa baru bisa melihat hasil dari usaha mereka yang hanya bisa diakses di Perguruan Tinggi Raharja.

Berdasarkan latar belakang yang ada, Perguruan Tinggi Raharja banyak mengalami permasalahan, diantaranya:

1. Bagaimana konsep paper based yang berjalan?

2. Bagaimana menerapkan konsep computer based iOU yang baik agar efektif dan efisien?

3. Apakah iOU efektif dijadikan sistem ujian online?

\section{LANDASAN TEORI}

\section{Definisi TPi (Ten Pillar IT iLearning)}

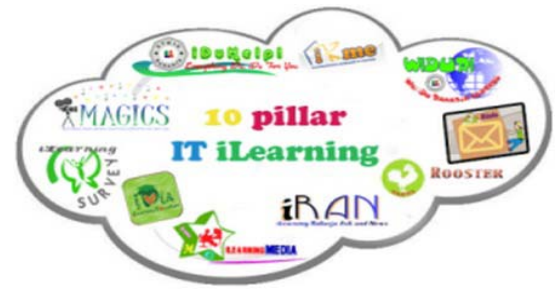

Gambar 1. TPi (Ten Pillar IT iLearning)

Konten-konten merupakan hasil dari penelitian Tridharma Perguruan Tinggi antara dosen dengan mahasiswa yang diwadahi oleh REC (Raharja Enrichment Centre). Para mahasiswa yang sedang melakukan penelitian bertugas untuk mengisi konten pada software yang sudah terinstall sesuai dengan kebutuhan. Copyright konten yang ada pada TPi seluruhnya adalah milik Perguruan Tinggi Raharja.

\section{Definisi iDu (iLearning eDucation)}

iDu (iLearning eDucation) merupakan media pembelajaran online guna mendukung pembelajaran konvensional. iDu adalah salah satu aplikasi dari TPi (Ten 
Pillar IT Ilearning) yang memanfaatkan ICT yang di kembangkan oleh Perguruan Tinggi Raharja secara online menggunakan Learning Management System (LMS) cloud-hosted tanpa perlu menginstal maupun men-download untuk memudahkan civitas kampus dan mahasiswa dalam menjalankan perkuliahan. Segala bentuk pembelajaran dapat dilakukan di iDu dengan mengkombinasikan tatap muka dan belajar online bagi mahasiswa/i dan dosen. iDu dirancang untuk menghasilkan proses belajar yang berkualitas dengan bimbingan dosen berpengalaman yang telah lulus iCP maupun iCM. Melalui iDu mahasiswa/i dapat berinteraksi dengan dosen maupun sesama mahasiswa/i secara anytime dan anywhere.

\section{Definisi iOU (integrated Online Ujian)}

Ujian Online iOU (integrated Online Ujian) adalah proses pelaksanaan Ujian Online di kampus Perguruan Tinggi Raharja yang dilaksanakan secara real-time (langsung) melalui iPad dan terkoneksi internet/wfi. Dengan pelaksanaan Ujian Online ini, maka peserta ujian atau Mahasiswa/i diwajibkan untuk mempersiapkan diri dengan membawa iPad-nya masing-masing dan terhubung dengan sambungan internet/Wifi pada jadwal yang telah ditentukan. Adapun jadwal ujian dapat dilihat melalui KPU (Kartu Peserta Ujian) masing-masing. iOU (integrated Online Ujian) pada kampus Perguruan Tinggi Raharja saat ini belum diperuntukkan untuk semua mata kuliah. Saat ini masih diperuntukkan untuk konsentrasi iLearning yang diselenggarakan ujian secara online, karena kelas iLearning adalah kelas yang menggunakan pembelajaran menggunakan media iPad.

\section{LITERATURE REVIEW}

Banyak dari literature review yang telah membahas tentang metode ujian online untuk dunia pendidikan. Dengan memanfaatkan internet untuk mengeksplorasi pendidikan. Sebagai landasan teori diperlukan studi pustaka untuk memperkuat hasil penelitian dan membandingkan tingkat keberhasilan dari penelitian yang telah dibuat. Beberapa literature review tersebut adalah sebagai berikut :

1. Penelitian yang dilakukan oleh Danny Wiliam Wongso dari Bina Nusantara tahun 2008 sebagai bentuk Skripsi dengan judul “Analisa dan Perancangan Piranti Lunak Pembangkit Soal Ujian Secara Online dengan menerapkan AJAX”. Pada tugas akhir ini penulis bertujuan untuk mengidentifikasi kebutuhan Universitas Bina Nusantara yang berkaitan dengan persediaan soal ujian, menganalisis dan merancang database, serta membuat aplikasi 
pembangkit soal ujian. Manfaatnya adalah untuk mendukung kemudahan proses penyediaan soal ujian sesuai Satuan Acara Perkuliahan (SAP) [2].

2. "Exploring Educational and Cultural Adaptation through Social Networking Sites” judul paper dengan penelitinya adalah Sherry D. Ryan dan Michael J. Magro dari University of North Texas, Denton, TX, USA dan Jason H. Sharp dari Tarleton State University, Stephenville, TX, USA(2011). Dalam penelitian ini, peneliti membahas tentang bagaimana Social Networking Site (SNS) bisa dijadikan media untukmengeksplorasi pendidikan. Bahkan peneliti menunjukan potensi yang dimiliki SNS dan tidak dimiliki LMS merupakan nilai lebih bagi SNS semacam Facebook. Namun, kekurangan yang dimiliki Facebook dimana Facebook tidak memiliki fasilitas untuk unggah dokumen seperti yang dimiliki LMS (moodle). Mungkin ini adalah kelemahan yang Facebook tidak miliki. Namun jika dokumennya berbentuk tulisan, tentu Facebook memiliki fasilitas berbagi dokumen pada grup Facebook. Fasilitas ini dinilai belum cukup untuk menyamai fungsi dari LMS seperti moodle [3]

3. Penelitian yang dilakukan oleh Sukriya dari ITS (Institut Teknologi Sepuluh Nopember) tahun 2009 sebagai bentuk Skripsi dengan judul "Perancangan Dan Pembuatan Perangkat Lunak E-Learning Berbasis .Net Menggunakan Teknologi Asp.Net 3.5Dan Ajax Dengan Partial Rendering Untuk Studi Kasus Scored Online Test”. Hasil pembuatan Tugas Akhir ini adalah ekplorasi teknologi baru Ajax Asp.Net serta pemanfaatannya dengan menggunakan studi kasus pembuatan perangkat lunak e-learning dengan scored online test. E-learning membawa pengaruh terjadinya proses transformasi pendidikan konvensional ke dalam bentuk digital, baik secara isi dan sistemnya. Begitu juga untuk mendapatkan feedback evaluasi pembelajaran secara cepat, tes online menjadi suatu alternatif untuk mendapatkan hasil yang optimal dengan pelaksanaan tes yang dapat dilakukan tanpa terhalang waktu dan tempat. Aplikasi yang mendukung hal ini biasanya berbasis web yang interaktif dan dinamik. Ajax Asp.Net 3.5 merupakan salah satu framework Ajax untuk Asp.Net [4].

4. Penelitian ini dilakukan oleh Gene Backlin dari tahun 2010 berjudul "Professional iPhone and iPad Application Development". Penelitian ini dilakukan dengan kebutuhan untuk membuat aplikasi top-notch untuk iPhone dan iPad Developers menuntut panduan lanjutan untuk menggunakan versi paling terakhir dari iPhone dan iPad SDK untuk mengembangkan aplikasidan buku ini menjawab bahwa panggilan. Dilengkapi lebih dari dua puluh aplikasi yang lengkap dan dirancang untuk menciptakan kembali, dibangun kembali, dan digunakan kembali oleh pengembang profesional, sumber ini 
menggali dunia semakin populer pengembangan aplikasi dan menyajikan panduan langkah-demi-langkah untuk membuat aplikasi yang superior untuk iPhone dan iPad. Alat pengembang banyak dan belajar bagaimana menggunakannya. Dengan cakupan versi terbaru dari iPhone dan SDK iPad dan jumlah aplikasi mandiri, buku ini akan menjadi luar biasa pergi-untuk referensi di masa depan. Dari Back Cover Membuat, membangun, dan menggunakan kembali aplikasi dengan SDK iPhone. Pengembang sedang mencari sumber canggih yang membawa mereka melalui apa yang sekarang menjadi pasar untuk iPhone serta pasar baru lahir untuk buku-iPad memenuhi bahwa permintaan ini. Profesional iPhone dan iPad [5].

5. Penelitian yang dilakukan oleh Matthew Young Kim di Kennesaw State University Kennesaw, GA, USA. Pada tahun 2011 dengan judul "Simulation Study of eLearning Classroom using iPads Based on Wireless LAN with IEEE 802.11b" menyajikan studi simulasi kelas e-Learning menggunakan iPad sebagai perangkat mobile berbasis pada LAN nirkabel dengan protokol IEEE 802.11b. Selain itu, makalah ini menyajikan sebuah studi simulasi apakah IEEE 802.11b dapat mendukung hingga 25 iPads dari kelas e-Learning tanpa masalah keadilan pada Wireless LAN bersama. Simulasi dilakukan dengan OPNET IT Guru Academic Edition 9.1 [6].

6. Penelitian ini dilakukan oleh Dr. Rory Lewis berjudul "iPhone and iPad Apps for Absolute Beginners” tahun 2010. Penelitian ini membahas tentang bagaimana Anda membangun sebuah aplikasi untuk iPhone dan iPad? Apakah tidak Anda perlu menghabiskan tahun-tahun belajar bahasa pemrograman yang rumit? Bagaimana Objective-C, Kakao Touch, dan SDK? Jawabannya adalah bahwa Anda tidak perlu mengetahui hal-hal itu. Siapa saja bisa mulai membangun aplikasi sederhana untuk iPhone dan iPad, dan buku ini akan menunjukkan kepada Anda bagaimana caranya [7].

Dari enam literature review yang ada, telah banyak penelitian mengenai sistem ujian secara online atau computer based. Namun dapat disimpulkan pula bahwa belum ada peneliti yang secara khusus membahas atau mengatasi masalah mengenai media penyimpanan soal atau bank soal yang dapat diakses seluruh dosen dan tersimpan otomatis kedalam sistem. Agar para dosen memiliki referensi dalam membuat soal bagi mahasiswa. Itulah alasan mengapa Perguruan Tinggi Raharja membutuhkan perubahan sistem ujian menjadi computer based, dimana tidak hanya menunjukkan kampus IT tetapi juga bisa menjadi andalan untuk Perguruan Tinggi Raharja dapat bersaing dengan kampus lain. 


\section{PEMBAHASAN}

Dari permasalahan yang ada, maka diperlukan penerapan sistem dengan konsep computer based, terlebih untuk suatu sistem informasi yang akurat. Kecanggihan iPad yang dimanfaatkan sebagai media penunjang berjalannya iLearning di Perguruan Tinggi Raharja. Kini belajar bukan hanya didalam kelas, bukan hanya di atas kertas, namun dengan iLearning kita menunjukan bahwa bisa belajar dimanapun dan kapanpun. Aktifitas apapun adalah belajar. Saat bermain dengan jari dan iPad, saat itulah sedang belajar. Menjelajahi dunia maya dengan mencari informasi yang sangat kaya dan berkualitas tentunya itulah belajar yang sesungguhnya. Bila mendefinisikan belajar adalah membaca, menulis, tentunya itulah metode pembelajaran yang kuno. Kita butuh perubahan karena kini dunia sudah begitu maju dan akan selalu membutuhkan perkembangan dari berbagai sisi. iOU (integrated Online Ujian) merupakan media pendukung pembelajaran iLearning yang berupa sebuah aplikasi. Diharapkan aktivitas serta prestasi belajar mahasiswa terhadap pembelajaran dapat meningkat dikarenakan dengan iOU (integrated Online Ujian) mahasiswa tidak lagi menjalankan ujian secara paper based, melainkan online. Fungsi dan manfaat media pengajaran juga dikemukakan oleh Sudjana [2002], bahwa “dengan penggunaan media pengajaran dapat mempertinggi pembelajaran siswa dalam pengajaran yang pada gilirannya diharapkan dapat mempertinggi hasil belajar yang dicapainya. Penggunaan media pengajaran pada saat terjadinya pembelajaran dalam kelas diharapkan dapat mempertinggi minat dan perhatian siswa dalam mengikuti pembelajaran yang sedang berlangsung. Hal tersebut dapat mempertinggi motivasi siswa untuk mengikuti proses belajar mengajar. Selain hal tersebut dengan penggunaan media pengajaran maka siswa dapat melihat secara langsung, tidak hanya dengan kata-kata sehingga diharapkan siswa dapat lebih mudah memahami apa yang disampaikan oleh dosen dalam kelas. Sedangkan menurut Levie dan Lentz khususnya media visual adalah: (1) fungsi atensi yaitu menarik dan mengarahkan perhatian siswa untuk berkonsentrasi kepada isi pengajaran yang berkaitan dengan makna visual yang ditampilkan, (2) fungsi afektif yang dapat mengubah emosi dan sikap siswa, (3) fungsi kognitif yang memperlancar pencapaian tujuan untuk memahami dan mengingat informasi atau pesan yang terkandung dalam gambar, dan (4) kompensatoris yaitu memberikan konteks untuk memahami teks dan memabantu siswa yang lemah dalam membaca dan mengorganisasikan informasi. Dari keempat fungsi dan manfaat media pembelajaran tersebut, maka dapat diketahui bahwa sesungguhnya penggunaan media pengajaran dapat meningkatkan kualitas hasil belajar mengajar yang diperoleh oleh siswa karena ketiga komponen kognitif, afektif dan psikomotorik dalam pembelajaran dapat dipacu. Hal tersebut dapat mempertinggi 
hasil dan prestasi belajar siswa dan sekaligus dapat mendukung dan mendorong siswa yang memiliki kemampuan yang terbatas dalam menerima informasi dan pesan dalam pembelajaran yang berlangsung. Efektifitas penggunaan media terhadap proses belajar mengajar tersebut terjadi karena dalam proses penggunaannya siswa dilibatkan tidak hanya dalam benak ataupun mentalnya saja akan tetapi dapat memperhatikan dan menyaksikan secara langung informasi yag disampaikan dalam pembelajaran tersebut.

Proses ujian merupakan proses evaluasi dan berlangsung secara berkala, maka konsep ujian merupakan salah satu komponen sistem pembelajaran yang vital. Dengan konsep paper based dalam pelaksanaan ujian banyak permasalahan terjadi dari berbagai sudut pandang, seperti :

\section{Waktu}

Dalam kegiatan administrasi persiapan soal-soal ujian banyak sekali kendala yang terjadi, dimulai dari pengumpulan soal yang diserahkan oleh dosen sering kali terlambat pengumpulan soal, hingga ditemukan beberapa soal yang tidak sesuai dengan Indeks Mutu Soal (IMS). Hal tersebut sudah terjadi berulangulang tanpa penanganan yang konkret.

\section{Tenaga}

Untuk tenaga pekerja pada pelaksanaan ujian yang tergabung dalam Panitia Pelaksana Ujian dan terbagi dalam beberapa beberapa koordinator sangat memakan banyak tenaga, karena karyawan yang bertugas tergabung dalam Panitia Pelaksana Ujian tidak hanya fokus mengerjakan hal tersebut tetapi juga harus mengerjakan rutinitas harian yang biasa mereka kerjakan.

\section{Hardware}

Dalam segi hardware yang terpakai yakni komputer untuk edit soal dan mesin fotocopy. Untuk komputer karena banyaknya dosen yang menyerahkan soal ujian melalui flashdisk mengakibatkan komputer RPU terjangkit virus. Dan untuk mesin fotocopy dikarenakan melakukan pengcopyan dalam jumlah besar, mesin menjadi panas dan rusak.

\section{Ketidak seragaman format soal}

Banyak keterlambatan dalam pengumpulan soal membuat dosen yang terlambat malas untuk membuat soal yang sesuai dengan Indeks Mutu Soal (IMS), dan itu membuat tambahan tugas bagi RPU untuk mengedit kembali dan memastikan format soal yang diserahkan oleh dosen.

\section{Pengawas Ujian}

Banyak dari para pengawas yang lupa akan jadwal mengawasnya hingga terlambat datang ke ruang pelaksanaan ujian. Hal tersebut juga mengakibatkan bagi mahasiswa yang telah datang ke dalam ruang ujian tidak bisa memulai ujian 
dikarenakan soal-soal ujian belum dibagikan oleh pengawas yang datang terlambat. Dan hal tersebut juga membuat mahasiswa menjadi rugi waktu dalam mengerjakan soal ujian.

\section{Peserta Ujian}

Bagi para peserta ujian yang berstatus mahasiswa baru belum tahu akan peraturan-peraturan ujian yang tidak dipublikasikan. Walau di kampus terdapat beberapa papan pengumuman atau biasa disebut mading, tetapi bagi mahasiswa zaman sekarang lebih memilih membuka jejaring sosial karena tampilan yang lebih menarik, sehingga dapat dikatakan pengumuman ujian paper based sudah tidak lagi diminati oleh mahasiswa.

Sehingga dengan permasalahan yang ada diperlukan sebuah pelaksanaan ujian dengan konsep baru untuk pembelajaran iLearning di Perguruan Tinggi Raharja dengan merancang sebuah aplikasi atau media penyimpanan soal dan nilai yang digunakan oleh dosen dan mahasiswa dalam pelaksanaan ujian. Aplikasi yang dirancang adalah iOU (integrated Online Ujian) aplikasi ini merupakan aplikasi ujian online untuk berbagai matakuliah. iOU (integrated Online Ujian) sendiri adalah sebuah aplikasi atau media penunjang sistem pembelajaran iLearning dalam segi ujian dimana di dalam aplikasi ini terdapat kumpulan-kumpulan soal yang berada di bank soal, fasilitas gradebook secara langsung, berbagai jenis assignment yang dapat dosen tentukan, fasilitas chat dan history jumlah matakuliah yang diujikan. Berikut adalah penjelasan dari 7 fitur unggulan yang ada pada apkilasi iOU (integrated Online Ujian)

\section{1. iLearning}

Sistem pembelajaran konvensional yang diterapkan secara modern. Oleh karena iLearning dikemas dengan sedemikian rupa dengan content-content pendukung. Sebagai penunjang untuk kegiatan belajar mengajar yang modern iLearning ialah mengintergrasikan teknologi untuk belajar, bermain, berdoa, dan bekerja.

\section{News}

Dengan adanya News di dalam iOU (integrated Online Ujian) ini berperan penting bagi mahasiswa jika ada pemberitahuan seputar matakuliah yang mereka sedang ampuh. Dan saat pelaksanaan ujian pun dosen dapat memberikan pemberitahuan melalui News.

\section{Calender}

Bagi sebagian mahasiswa terkadang banyak yang lupa akan jadwal kuliah, jadwal ujian atau hal-hal penting yang terdapat pada matakuliah yang mereka 
sedang ampuh. Calender di dalam iOU (integrated Online Ujian) ini memberikan kemudahan bagi siapa saja mahasiswa untuk lebih disiplin lagi.

\section{Assignment}

Mengacu pada tugas yang diberikan kepada mahasiswa oleh dosen. Assignment memungkinkan mahasiswa mendapatkan pengetahuan dan meningkatkan kemampuan secara mandiri dan berkomitmen.

\section{Gradebook}

Sebuah bagian dari iOU (integrated Online Ujian) yang dapat menampilkan hasil atau nilai secara online dan langsung setelah sesaat mahasiswa selesai mengerjakan tugas atau soal ujian yang telah ditentukan.

\section{Attendance}

Jika masih ada mahasiswa terlewat untuk tanda tangan absen saat ujian paper based, di iOU (integrated Online Ujian) hal itu tidak akan terjadi lagi. Dipastikan absen kehadiran mahasiswa akan terorganisir dengan baik karena pengawas ujian dapat langsung melakukan absen online di dalam ruang ujian \& pengawas tidak perlu lagi mendatangi setiap kursi mahasiswa untuk meminta tanda tangan.

\section{Analitytics}

Adalah kajian yang dapat dilakukan dosen terhadap mahasiswa guna mengetahui perkembangan dari mahasiswa tersebut setalah selesai mengerjakan tugas atau soal-soal ujian yang diberikan dosen.

Dalam aplikasi iOU (integrated Online Ujian) terdapat berbagai macam feature pendukung, yaitu adanya fasilitas assignment dan juga bank soal. Kemudian adanya fasilitas dosen untuk login pada saat ingin melakukan pembuatan soal maupun pemberian nilai. dalam aplikasi iOU (integrated Online Ujian) ini kita dapat melihat history dari nilai ujian dari masing-masing matakuliah yaitu di gradebook.

\section{IMPLEMENTASI}

Tampilan aplikasi (application) iOU (integrated Online Ujian) memiliki berbagai macam fitur yang dapat digunakan oleh mahasiswa maupun dosen yang terdiri dari :

\section{a. Tampilan Utama Aplikasi iOU (integrated Online Ujian)}

Aplikasi tersebut dapat diakses di luar kampus oleh dosen maupun mahasiswa dengan menuju alamat url idu.raharja.info 


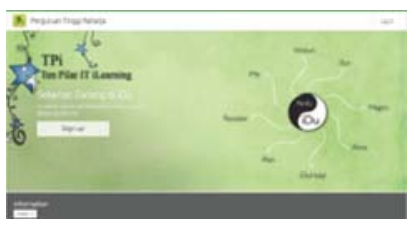

Gambar 2. Tampilan Utama iOU

\section{b. Tampilan Home}

Pada tampilan ini dosen mahasiswa bisa mengakses Classes yang sedang diampuh.

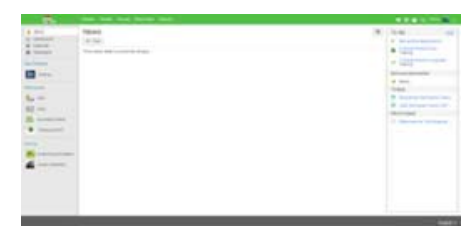

Gambar 3. Tampilan Home

\section{c. Tampilan News}

Tampilan ini memberikan informasi seputar kegiatan kampus kepada mahasiswa dengan News yang di post oleh dosen atau admin.

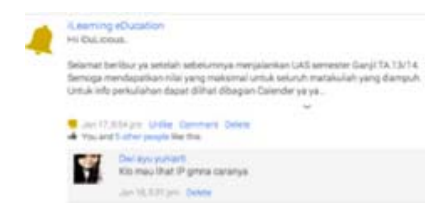

Gambar 4. Tampilan News

\section{d. Tampilan Calender}

Pada tampilan ini mahasiswa bisa melihat jadwal perkuliahan secara umum sepanjang 1 (satu) tahun akademik. Mulai dari jadwal mulai perkuliahan hingga waktunya pembayaran cicilan biaya perkuliahan.

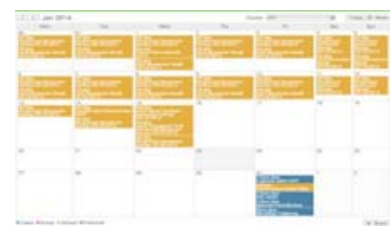

Gambar 5. Tampilan Calender 


\section{e. Tampilan Assignments}

Pada saat akan mengerjakan soal-soal yang diberikan dosen, mahasiswa dapat melihat langsung di assignments, pada assignments mahasiswa bisa mengerjakan soal sesuai waktu yang telah di setting oleh dosen. Dan dalam pengerjaannya mahasiswa dituntut untuk mandiri sehingga menciptakan kreativitas yang tinggi.

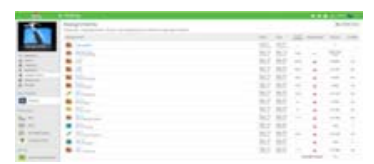

Gambar 6. Tampilan Assignments

\section{f. Tampilan Assignments Yang Telah Dipilih Mahasiswa}

Tampilan ini adalah pintu utama bagi mahasiswa yang akan mengerjakan soal-soal ujian yang telah dibuat oleh dosen. Hal ini diakses saat quiz maupun ujian berlangsung atau juga ketika dosen ingin menguji kemampuan mahasiswa secara personal dan lainnya.

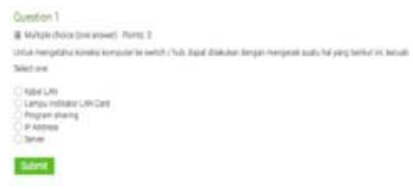

Gambar 7. Tampilan Assignments Yang Telah Dipilih Mahasiswa

\section{h. Tampilan Gradebook}

Setiap tugas atau assignments yang telah diberikan oleh dosen, dosen dapat melihat secara keseluruhan pada gradebook hasil dari pengerjaan tugas mahasiswa. Dan gradebook ini ditampilkan secara detail.

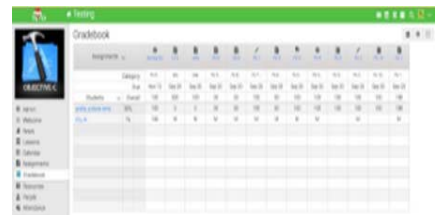

Gambar 8. Tampilan Gradebook

\section{i. Tampilan Attendance}

Dengan attendance, dosen dapat melakukan absen secara online walau sedang menjalankan perkuliahan secara offsite class. Sehingga kerajinan dari mahasiswa tersebut tetap dapat terdeteksi. 


\section{Gambar 9. Tampilan Absensi Mahasiswa}

Dari fitur iOU (integrated Online Ujian) yang diimplementasikan, sistem tersebut masih terdapat beberapa kekurangan, tetapi juga banyak memiliki kelebihan yang lebih mempermudah sistematik pelaksanaan ujian. Dan di bawah ini adalah penguraiannya :

\section{Kelebihan}

Dengan aplikasi iOU (integrated Online Ujian) ini dosen dan mahasiswa dapat memaksimalkan sistem pembelajaran iLearning pada saat pelaksanaan UTS maupun UAS sehingga belajar lebih efektif, efisien dan menyenangkan sesuai konsep iLearning. Beberapa kelebihan dari aplikasi iOU (integrated Online Ujian) ini adalah sebagai berikut :

1. Dengan iOU (integrated Online Ujian) pihak kampus dapat meminimalisir biaya

2. Dapat mengurangi tenaga karyawan

3. Menghemat waktu, baik itu waktu persiapan sebelum pelaksanaan ujian, pelaksanaan maupun setelah ujian berlangsung (mengoreksi lembar jawaban)

4. History nilai yang tersimpan dengan baik

5. Feedback langsung

6. Paperless

7. Memiliki bank soal

\section{Kekurangan}

Keterbatasan utamanya ialah aplikasi ini memerlukan jaringan internet yang cukup handal agar dapat mengakses iOU (integrated Online Ujian) untuk mengerjakan soal-soal ujian yang dilakukan oleh mahasiswa maupun melakukan pembuatan soal yang dilakukan oleh dosen. Kemudian sampai saat ini aplikasi iOU (integrated Online Ujian) hanya dapat digunakan oleh mahasiswa iLearning. Namun dengan keterbatasan yang ada, program ini tetap menawarkan fasilitas yang cukup baik agar iLearning semakin terdepan.

\section{KESIMPULAN}


1. Dari hasil penelitian konsep paper based yang berjalan saat ini sangat memiliki banyak kekurangan, sehingga membuat pengeluaran lebih besar. Sistem pembelajaran iLearning yang berjalan saat ini pada dapat dikatakan belum efektif. Hal tersebut dikarenakan sistem pembelajaran yang ada masih berjalan manual dan melibatkan banyak pihak sehingga memakan waktu lama dalam menyiapkan perkuliahan. Walau sudah didukung dengan media iPad namun dalam prosesnya masih terdapat dosen dan mahasiswa yang tidak memanfaatkan media tersebut dengan baik. Dosen-dosen masih merasa nyaman dengan sistem manual sehingga tercipta mahasiswa yang berkarakter sama.

2. Cara untuk mengimplementasikan sistem pembelajaran iOU (integrated Online Ujian) pada konsentrasi iLearning yakni dengan diterapkannya pelaksanaan tugas dan pelaksanaan UTS/UAS dilakukan menggunakan iOU (integrated Online Ujian). Hal ini sangat memudahkan bagi pihak-pihak terkait. Dan menciptakan proses yang berkualitas sehingga menghasilkan mahasiswa-mahasiswa yang memiliki daya saing tinggi. Tidak hanya itu, cara lain yang dilakukan adalah dengan menciptakan dosen-dosen berkualitas melalui training iCP.

3. iOU (integrated Online Ujian) sangat efektif sehingga dapat dimanfaatkan oleh Perguruan Tinggi Raharja untuk mengubah sistem ujian paper based menjadi computer based, yang dapat memberikan kemudahan bagi panitia ujian, dosen hingga mahasiswa secara efektif dan efisien. Dan menjadikan metode pembelajaran iLearning semakin terdepan.

\section{DAFTAR PUSTAKA}

[1] Rahardja Untung, (2011) “Definisi iLearning”. Raharja Enrichment Centre (REC). Tangerang.

[2] Danny Wiliam Wongso. “Analisa dan Perancangan Piranti Lunak Pembangkit Soal Ujian Secara Online dengan menerapkan AJAX”. Skripsi, Jakarta : Bina Nusantara. 2008.

[3] Ryan Sherry "Exploring Educational and Cultural Adaptation through Social Networking Sites”, USA: University of North Texas. 2011.

[4] Sukriya. "Perancangan Dan Pembuatan Perangkat Lunak E-Learning Berbasis .Net Menggunakan Teknologi Asp.Net 3.5 Dan Ajax Dengan Partial Rendering Untuk Studi Kasus Scored Online Test”, Jurusan Teknik Informatika, Skripsi, Surabaya : ITS. 2009.

[5] Gene Backlin“Professional iPhone and iPad Application Development”. 2010.

[6] Matthew Young Kim 2011 "Simulation Study of eLearning Classroom using iPads Based on Wireless LAN with IEEE 802.11b.

[7] Rory Lewis 2010 “iPhone and iPad Apps for Absolute Beginners”. 